小麦およびその製粉画分の植物学的成分 第 2 報・アミノ酸組成による定量

Jensen, S. A. and Martens, H.: Cereal Chem., 60, 172 177 (1983).

小麦の果皮，外種皮，糊粉層，胚乳，胚を分離してそ れぞれのアミノ酸組成を求め，製粉工程に打る50画 分の值と比較した。得られたデータの多重線形回帰分析 を行ない，製粉画分中における植物学的成分の存在比率 を推定した。果皮, 糊粉層拉よび肧乳の絬果に関して, ケイ光分析淿よる前報の結果と比较したところ，果皮と 胚乳に関してはよく一致したか，糊粉層に関しては相関 保数が小さかった。灰分, 糖質, ナイフシン等の化学成 分においては両グループの測定結果の相関がよいととか ら，本結果における相違は，ケイ光分析上りる，むしろ フミ/酸モデルが不十分であるためと考えられる。

(大坪研一)

\section{7 年から 1980 年までの英国の小麦粉の栄養成分}

Wenlock, R. W.: J. Sci. Food Agric., 33, 1310 1318 (1982).

英国政府による小麦粉の調査方式は1957 年に改定さ れた。製粉業界の協力を得 $て$ ，代表的な食用小麦粉が集 められ，国立研究所にて栄養成分分析が行なるれた。調 査はそれ以来継続的になされている。それぞれのタイプ の小麦粉の栄益成分はほぼー定であり，ほとんどすべて の成分の年次变動は $5 \%$ 以下であった。小麦粉および小 麦粉を基本原料とする食品は多量に消費されており，得 られたデーターは栄養面からみて重要であり，国民の平 均摂取量と関連うけけ議論されている。

（松會 潮）

\section{エンバクの種子および精白画分における}

リパーゼ活性の存在部位

Urquhart, A. A., et al.: Cereal Chem., 60, 181 183 (1983).

${ }^{14} \mathrm{C}$ ラデルした基質を用いて，エンパク種子のリパー ゼ活性を測定した。発芽後 24 時間で怡えどの活性が 胚以外の部位に存在した。精密なドリルで, 泼, 胚十胚

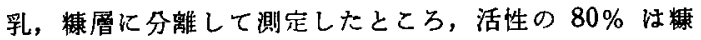
層に存在していた。脱稃エンバクを，精白段階により， 䗧層, 一次画分, 二次画分, 穀粉画分之 4 画分に分類 てリパーゼ活性を測ったところ，綠層と一次画分とに大 部分の活性が存在し，その比率は，水分含量 $12 \%$ の工 ンバクの場合で $69.2 \%, 5.1 \%, 24.7 \%, 1.0 \%$ であっ た。水分含量 7\% の凍結乾燥エンバクの場合は, リパー ゼ活性の存在比菜が，各々, $83.3 \%, 7.7 \%, 6.2 \%, 2.8$ \%であった。

(大坪研一)
ワイルドライスの色調に対する加工の影響

Schwartz, S. J., et al.: J. Agric. Food Chem., 31, 349 351 (1983).

ワイルドライス種子のクロロフィルフコェオフィチン および関連誘導体を，逆相カラムの高速液体クロマトグ ラフィー (HPLC) Kよって分析した。 $80^{\circ} \mathrm{C}$ 以上の高温 乾燥や焙煎処理を行なうと，クロロフィルがフェオフィ チン, ピロフェオフィチンおよびその他の誘導体に変化 しメラニンと結合して譹粒の黑変を引起こすことが示 された。本研究により，ワイルドライスの加工における クロロフィルの変化を測定するために，HPLC が有用で あると思われる。 (大坪研一)

大豆のイソフラボン組成におよぼす懪境と品種の影響

Eloridge, A.C. and KwoleK, W. F.: J. Agric. Food Chem., 31, 394 396 (1983).

大豆のインフラボンとインフラボンダルコシドにおよ ぼす環境と品種の影響を調べた。インフラボンおよびそ のグルコシドはーキサンに不溶なため，大豆から油を抽 出することによっては除去できなかった。全インフラボ ン量は，品種間に 119 から $309 \mathrm{mg} / \mathrm{g}$ の变動があり, 同一品種でる生育場所によって 49 から $195 \mathrm{mg} / \mathrm{g}$ の変 動があった。同一場所の栽培においても年次によって变 動した。イソフラボンは肧軸に惯縮されており，外皮に はきわめて少量しか含まれていなかった。

（松倉 潮）

\section{熱風乾燥大豆の品質評価}

Ghaly, T. F. and SutherLand, J. W.: J. Stored Prod. Res., 19, 31 41 (1983).

水分を $14,16,18 \%$ に調節した大豆種子 (Forrest) を 40, 50, 55, 60, 65, $70,80^{\circ} \mathrm{C}$ の風で 4 時間乾燥し， 品質への影響を調べた。また，水分を調節した種子を試 駼管内に密封し，40４5，50，55, $60^{\circ} \mathrm{C}$ の空気で加熱 し，一定水分下での加熱の影響を調べた。発芽力の変化 は，加熱被管の開始を明確に指し示した。安全な畭燥空 気温度は，初期の水分 $14 ， 16 ， 18 \%$ 飞打いて，そ九炎 れ $65,60 ， 55^{\circ} \mathrm{C}$ であった。油の收率, 遊離脂肪酸含量, 脂肪酸組成は，加熱处理によって影響を受けなかった。 しかし，過酸化物価拄乾燥温度 $50^{\circ} \mathrm{C}$ 以上で社幾分增加 した。室温での処理は発芽に影響を与えなかった。

（松倉 潮） 
四角豆種子中のトリプシンインヒビターの抽出性

TAN, N. -H., et al.: J. Sci. Food Agric., 33, 1327 $\sim 1330$ (1982).

四角豆種子中のトリブシンインヒどターの塩溶液炕よ る抽出性は，抽出液の $\mathrm{pH}$ とイオン强度によって变化し た。高イオン強度では $\mathrm{pH}$ が高くなるにつれて抽出性は 增加した。低イオン強度では $\mathrm{pH} 4$ において抽出性が最 低であった。 $\mathrm{pH} 7$ 以上で，高おょび低イスン強度のい ずれでも，同一の最大量のトリブシンインヒビターが抽 出された。四角豆蛋白の溶解性も同様な傾向を示した。 抽出されたトリブシンインヒビターの $95 \%$ が，硫安 30 〜 70\% 的和で沈殿した。硫安分画で得られたトリプシ ンインヒビターは， フルカリ $\mathrm{pH}$ 下， $100^{\circ} \mathrm{C} ， 10$ 分間の 加熱処理により完全に失活した。

（松倉 潮）

\section{大豆グリシニン含量の品種間差}

Hughes, S. A. and Murphy, P. A.: J. Agric. Food Chem., 31, 376 379 (1983).

同一環境条件で栽培した 10 品種の大豆のグリシニン （11 S 蛋白）含量を SDS ポリアクリルアミドゲル電気 泳動炕よって調べた。10 品種の全蛋白含量は 39.4 から $44.1 \%$ の範囲にあった。全蛋白当りのグリシニン量は 31.4 から $38.3 \%$ であった。全重量当りのグリシニン量 生 13.5 から $17.8 \%$ であった。全蛋白含量が高いこと とグリシニン含量が高いことは必ずしむ関連していない が，この相関関保は高かった。グリシニン壮ゲル化能を 有して㧍り，大豆食品の製造に重要である。品種間汇差 が存在することの確認と，これらの差を定量する方法の 適用は，大豆食品䌘造のための大豆の選抜の助けになる と思われる。 (松倉 潮)

ミネラルおよび大豆を強化したパンからの マグネシウムの相対生物利用率

Winterring, G. L. and Ranhotra, G. S.: Cereal Chem., 60(1), 14 (1983).

栄養強化の桩大がパン中のマグネシウムの生物利用率 にどのような影響を与えるかについて検討した。生物利 用事法バン以外の食品で求めた回帰方程式（血清および 大腿骨のマグネシウム含量に基うくをを使って算出した。 供䛋バンのマグネシウムの $55 \%$ は小麦粉由来のもので あり，あとの $45 \%$ は炭酸マダネシウムおよびこれと脱 脂大豆粉を併用したものに由来していた。単一のンース (小麦粉，大豆，炭酸マグネシウム）からのマグネシウ ムの方が生物に利用され易いことを示唆するようなパタ ーンは現われなかった。これは一部は供試パソのマグネ シウム吸収において，あるいはラットの継維排泄パター ンにおいて，大差かなかったととによるものかもしれな w。

（田中康夫）

\section{スクシニル化ホエー蛋白濃縮物のフアリノグラフ} 特性とパン品質に対する影響

Thompson, L. U. and Baker, L. M.: Cereal Chem., 60 (1), 71 73 (1983).

スクシニル化ホエー蛋白濃縮物 (SWC) を小麦粉に添 加したとき，脱脂粉乳やホエー浱縮物を添加した場合と 比べて生地の形成時間と安定性が低下した。また SWC を添加してハンン焼き上げた場合，体穑，軟らかさ，受 容性，表皮色の明るさなぞがいずれも低下を示した。 SWC は高い吸水能を示すにすかかからず，パンの老化 遅延に対してはあまり奻果を示さなかった。SWC の製 パン效果を改善する目的でソジウムステフロイルー2-ラ クチレート皆添加してみたが，西まり有勃ではなかっ た。結局スクシニル化によってホエー濃縮物の製パン性 を改善することはできないようである。（田中康夫）

\section{乾燥方法が植物蛋白濃縮物の機能性におよぼす影響}

KNORR, D. and Betschart, A. A.: Stärke, 35, 23 $\sim 28$ (1983).

乾燥方法が米脻蛋白と大豆蛋白凝固物の組成と機能性 におよほす影響を調べた。凍結、スプレードラム乾燥 によって，租成に若干の差がみられた。加熱凝固させた 試料の蛋白溶解性に対し，乾燥方法の差はある限定され た影響を及ほした。室温で疑固させた大豆蛋白をドラム 乾燥した場合，蛋白溶解性は顕著に低下した。吸水性々 乳化性注乾燥方法によって著しく影響をうけた。一方， 脂肪吸収性は一定の傾向が認められなかった。概して,

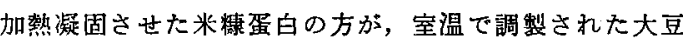
蛋白濃絔物よりむ，乾燥方法によってうける影岞に一貫 性があった。

（松倉 潮）

\section{葉蛋白濃緶物の栄㡙評価方法}

Maliwal, B. P.: J. Agric. Food Chem., 31, 315 $\sim 319$ (1983).

9 種の植物の葉蛋白源縮物化ついて，化学的方法によ ってインビトロの消化率とアミノ酸組成を，また，動物 試験によって真の消化率と正味蛋白比を調べた。各試料 間にアミ/酸組成, ペブシンおよびペプシンーパンクレ アチンによる消化性，さらに，動物試験による摄食量， 生長，消化率に䫓著な差が認められた。インビトロとイ ンビボの消化率の間，含硫つミ/酸量と正味蛋白比の 間，および，種々のアミノ酸と有効性りジンの变動に相 関関係方認められた。ペプシンーパンクレナチンによる

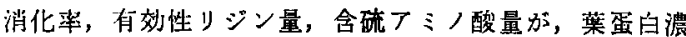
縮物のインビトロにおける鋭敏かつ迅速な栄䔄評価方法 として有用であると思われた。

（松食 潮） 


\section{ナタネ蛋白分離物：蛋白質の収量と組成に} 与える処理工程の影響

Blalcher, F. M., et al.: J. Agric. Food Chem., 31, 358 362 (1983).

脱脂ナタネミールを $\mathrm{pH} 9.5$ と $\mathrm{pH} 12.0$ で交互に運 続的に向流抽出することにより，蛋白質 $(95 \%)$ とフィ チン酸 $(70 \%)$ が最も效率よく抽出された。抽出液它 $\mathrm{pH} 6.0$ つついて $\mathrm{pH} 3.6$ に調整して，全蛋白質の 60 \%と $12 \%$ にあたる 2 つの分離蛋白画分を得た。これら 画分のフィチン酸含量は $9.8 \%$ と $4.3 \%$ であった。 $\mathrm{pH}$ 4.0 で抽出するとミール中のフィチン酸の $70 \%$ が除去

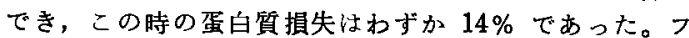
イチン酸除去後， $\mathrm{pH} 11.0$ で抽出し， pH 4.7 で沈殿さ せるとフィチン酸含量 $0.2 \%$ の蛋白画分を得ることがて きた。蛋白分離物の色調は $\mathrm{NaHSO}_{3}$ 処理で改善された。 フィチン酸 $10 \%$ を含む蛋白試料はカゼインに匹適する 㔻白効率を示した。

(麻生慶一)

綿実粉の機能特性に与えるアセチル化

\section{およびサクシニル化の影響}

Rahma, E. H. and Narasinga Rao, M. S.: J. Agric. Food Chem., 31, 352 355 (1983).

綿実蛋白質のてセチル化により，水あるいは $5 \% \mathrm{NaCl}$ 可溶性窒素量は減少したが，サクシニル化では逆に増加 した。蛋白質の吸水性はサクシニル化によって影響をう けなかったが、フセチル化により向上した。高度にてセ チル化またはサクシニル化すると吸油性の低下がみられ た。フシル化度の低いところでは㲎化性は向上したが， フシル化が進むにつれ低下した。フシル化にともない， 起泡性は良くなるが泡沫安定性は墨くなった。試駼管内 消化試験では修飾による大きな变化は認るられなかっ た。

(昨生慶一)

\section{デンプン製造副産物によるパン品質の改善}

El-Saied, H. M.: Cereal Chem., 60(2), 131 134 (1983).

コーンおよび米から湿式粉碀法によってデンプンを製 造する際に副生するコーングルテンウオーター(CGW), ライスグルテンウオーター $(\mathrm{RGW}) ，$ ライススティーブ ウオーター (RSW) などの水性副産物を，小麦粉 $100 \mathrm{~g}$ 当り窒素で $17 \sim 50 \mathrm{mg}$ 相当量添加し，製パンを行なっ た。これらの添加によって，イースト無添加生地の物理 的性質，つ勿地の伸長抗抗，伸長度，吸水能，混揘 要求量などが改善され，また $10 \%$ 小麦粉奬濁没の糊化 特性も改善された。また CGW，RGW，RSWの添加に よってパン (Balady および European) の品質も改善 されたほか，タンパク含量む増大された。バラディ・ブ レッドの蛋白の举䉵価はほとえど同じで，不足フミノ酸 はスレオニン，人チオニン，インロイシン，リジンなど であった。 (田中康夫)
比色法による，澱粉，デキストリン， CMC， 及びガム中のポリビニルアルコール定量法

HARShe, S. N., et al.: Die Stärke, 35, 18〜22 (1983).

ポリビニルアルコール (PVA) は幾つかの工業；例え ば織物工業のサイジングや仕上げ等で，広く利用されて いる。本報で注適当な PVA の定量法として，硫酸-ヨ ウ素試薬を用いた比色法による方法を検討した。本法 は，従来のホウ酸一ヨウ素法等に見られたような温度に よる色調の変化がなく, 又経時的にも非常に安定であっ た。本法により，粉体中及び水溶液中の，あるいは，デ ン粉デキストリン，CMC，グフガムに粉末やペースト状 で添加された PVA を非常に正確に定量することができ た。

(弥武経也)

\section{アミロース加水分解物のゲルクロマト グラフィによる研究}

Praznic, W., et al.: Die Stärke, 35, 58 61 (1983).

Sephadex G-200 よ Sepharose 2 B のカラム定連結 したゲルクロマトシステムを用い，馬鈴薯 フミロース （以下単に丁ミロースと略）の加水分解物について検討 した。無機酸によるてミロースの加水分解物の溶出カー ブは，高分子及び低分子フミロース両者どちらす，分解 が詨数関数的に進行すること表わす，同様のパターン

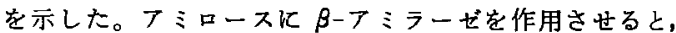
分解産物の分子量分布が多様であることを示す，幅広い 溶出パターンが得られた。またこの時，高分子丁ミロー スの分解は，平均的及び低分子のむのに比べかなり迫 い。このことは， $\beta$ ーフミラーゼによるてミロースの分解 が，multi chain 式に進むことをよく示㖟する。

(弥武経也)

アミロースーヨウ素椱合体の共鳴ラマンスペクトル

Pfannemüller, B., et al.: Die Stärke, 35, 7 11 (1983).

フミロースーヨウ素複合体形成において，適当なヨウ 素連鎖の長さの存在の有無，あるいは，フミロースの重 合度 (DP) に相関した結合ヨウ素種の変化について検討 するため，フミロース（DP 20-200）及び純粋なマルト オリゴ楉（DP 3-18）を用い，共鳴ラマンスペクトルを 測定した。アミロースーヨウ素複合体において観察され る, $162 \mathrm{~cm}^{-1}$ のメインシシグナルは，マルトオクタオ 一ス（G 8) において子観察された。一方，直鎖 G6で は同シグナルはもはや観察されないが， $\alpha$-サイクロデキ ストリンでは明瞭に観察された。ヨウ素連鎖の長さに相 関した結合ョウ素種の变化は，ラマンスペクトルからは 全く認められなかった。ヌラマンスペクトルは, 複合体 溶液の $\mathrm{I}_{2} / \mathrm{KI}$ 比を変えても，全く影響を受けなかった。 (弥武経也) 
ワキシーコーンスターチ及びアミローススターチの

電気透折における，段階的溶出による分折

$\check{C}_{\mathrm{EH}}$, M., et al.: Die Stärke, 35, 48 53 (1983).

加熱分散による，ワキシーコーン及びフミローススタ 一チの，ソルとゲル画分の変化を段階的溶出法により検 討した。ゲル及びソルの各画分は，ペースト系と，それ を $120^{\circ} \mathrm{C}$ のオートクレーブで処理した分散系から，電気 透析により分離した。加熱分散過程において，ワキシー コーンスターチのペーストのゾルとゲル画分は各ヶ，フ ミローススターチの同画分に比べ，より激しく分解され ることがわかった。ワキシーューンスターチのペースト のソル画分は，激粉全量の約 $9 \%$ が含まれるのみであっ たが，3時間のオートクレーブ処理により，45\%にをで 增加した。一方てミローススターチでは，この棁な増加 は観察されなかった。 (妳武経也)

\section{過酸化脂質に誘引される $\beta$-サイクロデキストリン の酸化分解}

KAWAKISHI, S., et al.: Die Stärke, 35, 54〜57 (1983).

リノール酸の自動酸化により誘引される, $\beta$ けサイクロ デキストリン $(\beta-\mathrm{CD})$ の酸化分解を， $\beta-\mathrm{CD}$ とリノー ル酸の混合物を用いた固体系で検討した。 $\beta-C D$ はリ 一ル酸の連鎖的酸化と一緒に酸化され，そのグルコシト 結合は分解された。またこの分解は，この系の水分含量 に比例して進行した。 $\beta-\mathrm{CD}$ は酸化分解により種々の才 リゴ榶を生じ，それらは邉元末端側に，Dーエリトロース， D-アラビノース，D-エリトロペントスロース，D-キシロ ペントジフルドース，D-グルコース等を持つ。 $\beta-C D$ の 分解は，リノール酸の過酸化において形成される，ある 種のラジカル種が引き起こすと考えられる。

(弥武経也)

\section{ブドウ果実の褐変-果実の生長と成熟中の}

ポリフェノールオキシダーゼ活性の変化

CAPIS, J. C., et al.: J. Agric. Food Chem., 31, $342 \sim 345$ (1983).

5 品種のブドウ果実の生長と成熟期間中におけるポリ フェノールオキシダーゼ活性について 3 年間にわたり調 查した。その結果，緑色の未熟期加ら完熟期にかけて非 常に複雑な変化を示すことが判明した。ポリフェノール オキダーゼ全活性と可溶型ポリフェノールオキシダーゼ の強度や活性発現の速度は年によりかなりの変動が見ら れた。ポリフェノールオキシダーゼ活性に対し品種の要 因柱全可盗型において特殊性が認められた。

（垣内典夫）
テンプルオレンジのエッセンスと水成エッセンスの組成 Moshonas, M. G. and Shaw, P. E.: J. Agri. Food Chem., 31, 334 336 (1983).

果実のエッセンスオイルや水成エッセンスは，果汁を 濃縮する際の最初の浱縮工程の留分の凝縮により得られ る。オレンジとマンダリンの自然交雑により生じたと考 えられる香気の優れたテンプルオレンジジュースから， エッセンスオイルと水成エッセンスの 2 種類を得, 香気 成分について GC 及び GC-MS 分析定行い，その組成 を調べた。水成ェッセンスからは 28 種の成分が，また エッセンスオイルからは 38 種の成分が検出，同定され た。とれらにはこれまでに未報告の $r$-Cardinene と nootkatol の 2 成分が確認された。また普通のオレンジ 果汁とは異なり，片親のマンダリンに由来すると考光ら れる多くの異質の香気組成が認められた。（垣内典夫）

グレープフルーツの葉と枝の生長に伴うリモニンの分布

McIntosh, C. A. and Mansell, R. L.: J. Agric ${ }^{\circ}$ Food Chem., 31, 319 325 (1983).

グレープフルーッの limonin の含量について個々の 樹体での葉及び枝に就ける分布を調べた。limoninは一 枚の葉内ではほほ均等に分布し，また特定の枝内でのそ れぞれの葉の濃度は，枝の令にかかからず一定であっ た。一枚の葉中の limonin 含量の絶対量は，葉の大小 により変化した。 limonate A-ring monolactate limonin の生成に反映される limonin 代謝能は， 1 樹 体内でもすべての枝で異なっていた。limonin 含量は， 葉芽のときから生長段階に多く，成葉あるいは葉色が濃 緑色となる段階では減少していった。葉中の limonin と limonate A-ring monolactone の比は葉の生長につ れて変化すること定認めるとともに，てれら成分の代謝 と蓄積の動態を明らかにした。

(垣内典夫)

ラビットアイブルーベリー中の揮発性成分の GLC-MS 分折

Horvat, R. J., et al.: J. Food Sci., 48(1), 278 279 (1983).

ラビットアイブルーベリー (Vaccinium ashei) から ベリーの約 $25 \mathrm{ppm}$ の量で水蒸気蒸溜による揮発性油分 が得られた。キャピラリガスクロマトグラフィー質量分 析による分析の結果，多量成分はェチルフセテート，リ モネン，人キサノール，cis-2-へキセノール，人プタ， 一ル，シネロロン， $\beta$ シリン，テルピネン-4-オール， 2-ウンデカノン， $\alpha$-テルピネオール，1-カルベオール， ネロール抢よびオイゲノールであった。同定された 42 の化合物のうち，29 はプルーベリーの揮発性成分とし てこれまで報告されていないるのであった。

(安井明美) 
地中海ミバエの駆除に対するメチルブロマイドの くん蒸効果と残留性

Tebbets, J. S., et al.: J. Agric. Food Chem., 31, $247 \sim 249$ (1983).

果実に付着して移動する地中海ミパェの駆除には，通 常果実を $0 \sim 2.2^{\circ} \mathrm{C} て ゙ 10 〜 16$ 日貯蔵ないしはメチルブロ マイド (以下 MB) ヌはェチルジブロマイト (CDB)く 乙蒸後 $0.6^{\circ} \mathrm{C}$ (4日) 加ら $13.3^{\circ} \mathrm{C}$ (10日) 保蔵する方 法が採用されているが，MBくえ蒸のみによる駆除効果 を検討した。セイヨウナシ，ブラム，オウトウ，ネクタ リン及びモモ果実に $48 \mathrm{~g} / \mathrm{m}^{3}\left(21^{\circ} \mathrm{C}\right)$ の 2,3 時間, $32 \mathrm{~g} / \mathrm{m}^{8}$ 処理を行ったところ，セイヨウナシとプラムは 他より吸収量が少なかったが，無機ブロムの残留量は女 イヨウナシを除けばいずれも許容基準值以下で，駆除効 果があった。セイヨウナシとプラム性，有譏態ブロムの 残留が多く残留時間も長かった。また有機態ブロムの消 失は处理直後 $24 \sim 48$ 時間内に急澈にみられ，低温貯藏 中でも同様であった。 (垣内典夫)

\section{一定のガス環境組成のモニターシステムの開発}

J. Agric. Food Chem., 31, 443 444 (1983).

CA 貯蔵庫や密封容器などのガス組成を变動させるこ となく連続的に検知することは非常に困難であるが，効 率の良い方法を開発した。連続的なガスの抜き取りが可 能で，しかる外気とのガスの混合は全く生じない簡便な 方法である。また，この装置は食品の包装や貯蔵庫のガ ス組成の管理のみならず，放射性ガスの安全な取り扱い あるいは病原細菌などを含む気体の管理にも有効であ る。

（垣内典夫）

\section{ニンジンの遊離糖含量に及ぼす数種殺虫唷と 除草剤の影響}

Rouchard, J., et al.: J. Agric. Food Chem., 31, 206 210 (1983).

有機リン性殺虫绪 Nexion, Birlane, Dyfonate と尿 素系除草剂 Afalon Spezial と Dosanex の散布がニン ジンの遊離煻含量に及济す影望を検討した。数回の栽培 試験を行い次の結果を得た。ニンジン根茎の遊離糖はフ

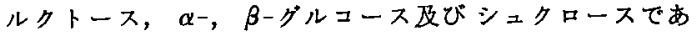
るが，殺虫戍の土壌処理ではいずれの薬戍とも無散布に 比べ，遊離糖は増加した。特に Birlane そ Nexion で 增加率が高かった。除草靔の Afalon Spezial は, ニン ジンの遊離糖含量に影響を及ほさなかった。一方，除草 都の Dosanex は遊離糖のいずれも減少し, 全桾含量が 減少することが明らかになった。
(垣内典夫)

\section{Agaricus bisporus の栽培における} 黄緑カビの生物的制御

Tautorus, T. E. and Townsley, P. M.: Appl. Environ. Microbiol., 45, 511 515 (1983).

マッシュルーム (Agaricus bisporus) の䇥培中比打 ける雑菌 Chaetomium olivaceum（黄緑カビ）它生物 的に制御する方法定開発した。耐熱性の Bacillus sp. は C. olivaceum に对して阻害勃果が認められたので， マッシニルームの一般的な培垱基及び水耕载培用の培盖 基に本菌を接種し，その効果を検討した。その結果，本 菌は C. olivaceum による被害を抑制するのみでなく， Agaricus bisporus の収量も増加することが認められ た。

(新国佐幸)

Rhizobium trifolii による抗菌性物質および ハクテリオシン様物質の生産

JosepH, M. V., et al.: Appl. Environ. Microbiol., 45, $532 \sim 535$ (1983).

R. trifolii IARI 株と Rel-1 株は各々広い抗菌活性と 狭い抗生活性它有する物質を生産した。指標菌に対し て, IARI 株と Rel-1 株は種々のサイズの増殖阻止域を 生じた（各々 2〜14 mm と 2〜6 mm)。両株によるこ れらの物質の生産は，Lーフラビノース寒天を用いた場合 に最大量を示した。IARI 株によって生産された抗菌性 物質は，耐熱性であり (75〜80 $\mathrm{C} ， 45$ 分間)，トリプシ ン，リゾチーム，DNase I および RNase A に感受性 はなかった。一方 Rel-1 株によって生産された物質は， 熱変性を受け $\left(75 \sim 80^{\circ} \mathrm{C}, 45\right.$ 分間)，またトリプシンに 感受性を有しリゾチーム，RNase A および DNase I には感受性はなかった。

(森 勝美)

飲料水からの大腸菌群の改良検出のための新しい培地 LecheVallier, MaRk W., et al.: Appl. Environ. Microbiol., 45, 484〜492 (1983).

飲料水から損傷を受けた大腸菌群検出のためのメンブ ランフィルター用培地を開発した。この培地は $\mathrm{m}-\mathrm{T} 7$ 培地と名づけられた。組成は蒸留水 $1 l$ 当り, Difco-ブ ロテオースペプトン No. $35.0 \mathrm{~g}$ ，ラクトース $2.0 \mathrm{~g}$, 酵母エキス $3.0 \mathrm{~g} ，$ タージトール 7 (25\% 演液) $0.4 \mathrm{ml}$, ポリオキシェチレンェタノール W-1 $5.0 \mathrm{~g}$, プロムチ モールプルー $0.1 \mathrm{~g}$ ，プロムクレーゾールパープル 0.1 $\mathrm{g}$, 寒天 $15 \mathrm{~g}$ である。選択削として滅菌培地 $1 \mathrm{ml}$ 当 り $0.1 \mu \mathrm{g}$ の Penicillin Gを添加した。m-T7 寒天培 地は遠藤寒天培地と比較して 86 99\% 以上の損傷大腸 菌群を検出することができた。飲料水から損賃を受けた 大腸菌群分離のためには，m-T7 寒天培地は遠藤寒天培 地よりすぐれていることを明らかにした。(上田成子） 


\section{微生物の相互作用研究への隔膜技術の応用}

NordbRING-HeRtz, B.: Appl. Environ. Microbiol., 45, 290 293 (1983)

隔膜技術について以下のようにまとめた。（i） 寒天 平板上でのカビの培養，（ii）直接検鏡による増殖の観 察，(iii) 寒天上からの菌体の収集とつつく処理または 生化学的分析, (iv) 走査電子顕微鏡観察。この技術は, カビと線虫類やカビとカビの間の相互作用の研究に系統 的に利用した。

(森 勝美)

\section{微生物試験用サンプルの自動希釈装置}

Trinel, P. A., et al.: Appl. Environ. Microb!ol., 45, $451 \sim 455$ (1983).

190 本の試験管を備えた，液体や土壤の㲘濁液を無菌 的に自動希积する装置について記載した。10 倍希釈液 列は $10^{-1}$ から $10^{-9}$ まで設定でき，スクリューキャップ とシリコン分離壁を備えたガラス管に 導入される。 $E$. coli と B. stearothermophilus について行なった 希釈 試験では，針の隇菌が適正に行なわれれば，本自動希䆏 装置牥，最も精度の良いこれまでの希釈法之同程度の正 確さを有する。

(森 勝美)
パーム油とココナッッ油の成分特性，加工及び利用性 Young, F. V. K.: J. Am. Oil. Chem. Soc., 60(2), 374 379 (1983).

パーム核オイルとココナッッオイルはラウリン酸系油 脂として最も多く利用されている。この采統の油脂はラ ウリン酸やミリスチン酸などの飽和脂肪酸が多い特徵が あり将来的な利用性の方向を示した。トリグリセライト 組成に基づく溶融性からハードパター,フイスクリーム， 石睮などに広く用いられているが加水分解や微量金属に よる接触酸化を受け易い。そこで，これら油脂の品質や 種々の利用適性を改善するため，水素付加や分画あるい はェステル化を種々の条件下で試み，検討を加えた。分 画は乾式圧搾や洗浄あるいは溶剂助用で行ったが，溶绪 を用いることにより高品質の製品とすることができた。 また，比較的高い脂肪酸の溶解性から，脂質が流出する 問題点が指摘された。
油ヤシからのパーム油の製造

Berger, K. G.: J. Am. Oil Chem. Soc., 60(2), 206 210 (1983)

油ヤシ (Elaeas guineensis) からパーム油を製造する 能率的工程を示した。熟果果房を採収後オイルミルにか けて処理する。殺菌，脱粒，果肉の破砕，スクリューブ レスでの圧㞰工程を経て，水と混合しタンク中で果肉残 渣を除去後，遠心分離によりオイル分を分け乾燥して貯 蔵する一連の工程が設定される。オイルの収量は生鮮果 肉量に対し $22 \% て ゙ ，$ 核を抽出するとさらに $5 \%$ 収率は 上昇する。製造工程中に打けるオイルの加水分解や酸化 による品質劣化を防止するための種々の技術について具 体的事例で解説した。

(垣内典夫)

Corynebacterium \$98によりチーズホエー基質中

に生成されたエキソポリサッカライドの特性

Shams, M. A. and JAYnes, H. O.: J. Food Sci., 48, 208 211 (1983).

Corynebacterium \# 98 は，ラクトース， $\mathrm{MgSO}_{4}$, $\mathrm{FeSO}_{4}$ を添加した $1.5 \%$ ホエー培地中で最適条件の $\mathrm{pH}$ $7.0,30^{\circ} \mathrm{C}$ 攪挥と $1090 \mathrm{ml} / \mathrm{min}$ のエアレーションによ り，オレンジ色のガムを生成した。ガムの粘度は濃度に ともない増加し，温度と $\mathrm{NaCl}$ 濃度により隇少した。主 にカリウム,ナトリウム，リン酸塩からなる $29.7 \%$ の 兏分が存在した。同定されたガムの構成成分は，ラム， 一スキシロース，マンノース，ガラクトース执びグ ルクロン酸とマンヌロン酸であり，その重量比は $2: 1: 6$ :6:7:16:11 であった。

(橋詰和宗)

冷荿中のプレーンヨーグルトの酸度变化に およぼす初期酸度の影響

SALJI, J. P. and IsmaIl, A. A.: J. Food Sci., 48, 258 259 (1983).

プレーンョーグルトの初期酸度と冷蔵中の酸度変化の

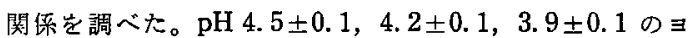
ーダルトを調製し， $4^{\circ} \mathrm{C}$ と $7^{\circ} \mathrm{C} て ゙ 3$ 週間冷蔵した。 $\mathrm{pH}$ と滴定酸度は毎週測定した。初め低い酸度（高い $\mathrm{pH}$ ) の試料は，冷蔵中に著しい酸度の増加 ( $\mathrm{pH} \mathrm{4.59 \rightarrow 4.15)}$

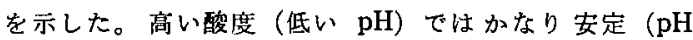
$3.82 \rightarrow 3.77)$ であった。酸度变化は $4^{\circ} \mathrm{C}$ に比べ, $7^{\circ} \mathrm{C} て ゙$ 著しかった。をたその変化は初めの 1 週間で大きく，そ の後は小さかった。

(橋詰和宗) 
ハイビスカス Sabdariffa 種子油の脂肪酸組成

Ahmed, A. W. K. and Hudson, J. F.: J. Sci. Food Agric., 33, 1305 1309 (1982).

西スーダンの各地から採集したハイビスカス Sabdariffa 種子油の脂肪酸組成を調べた脂肪酸パターンの 遑いが観察され，特にリノール酸 (30.1-37.45\%)， エ ポキシオレイン酸（痕跡 $-5.3 \%$ ）が顕著であった。シク ロプロペン酸のマルバル酸 (0.4-2.0\%) は以前報告さ れた值と異なっていた。また種子油汇性，他品種ハイビ スカスにおいて以前報告されたジヒドロステクル酸 $(1.0$ -1.6\%）も含んでいた。その他の脂肪酸は，ミリスチン 酸 0.2-0.5\%，パルミチン酸 $17.4-22.6 \%$ ，ステフリン 酸 3.9-5.2\%，オレイン酸 34.6-39.8\% であった。

(山崎 恵)

\section{Micrococcaceae の耐熱性におよぼす 卵黄と食塩の影響}

Verrips, T. and ReneE van RheE: Appl. Environ. Microbiol., 45, 1〜5 (1983).

卵黄や食塭加卵黄中での Micrococcaceae の種々の菌 株の耐熱性と增殖能を調べた。卵黄中では Micrococcaceae は顕著な耐熱性を示した。Staphylococcus aureus S6 は水中で法 $55^{\circ} \mathrm{C}$ に打いて $D$ 值 66 秒であったのが, 卵黄中では 246 秒であった。食塩加卵黄 (水分活性 0.95) 中では，S. aureus S 6 は $66^{\circ} \mathrm{C}$ において $D$ 值 180 秒 であり，一般のパスッリゼーション中は大部分失活して いた。 Micrococcus saprophyticus \&S. epidermidis (同条件下の $D$ 值がともに 390 秒) はこのような処理で はある程度生残可能であり，商業べースの卵黄を腐敗さ せ得る。

(森 勝美)

\section{エビ脂質の特徵}

Johnston, J. J., et al.: J. Food Sci., 48, 33 35 (1983).

エビ (Penaeus aztecus) の可食部には約 $1.2 \%$ の脂 質があり，リン脂質が主成分であった。カラムクロマト の結果，リン脂質としてはフォスフォチジルコリンが, 中性脂質としてはコレステロールが主であった。脂肪酸 分布の特徴としては，スフィンゴミェリンに最も不䳌和 酸が多く、これに対して，飽和酸の大部分はコレステロ ールエステルに存在した。またフフォスフォチジルコリ ン、フォスフォチジルエタノールフミン，フォスフフチ ジルセリンでは， $\alpha$ 位と比べて， $\beta$ 位の不跑和度が高か った。 (中添純一)

\section{ボラ落身の水晒し効果}

Tseo, C. L., et al.: J. Food Sci., 48, 163 167 (1983).

ボラ落身の品質向上への水晒し勃果を評価した。TBA 值注一般に 水温 $\left(5 \sim 35^{\circ} \mathrm{C}\right)$ が高くなるにつれ 隇少した が，更に高水温では增加した。水温 $35^{\circ} \mathrm{C}, \mathrm{pH} 6.0$ 以上 では TBA 值は減少した。最大白度, 最低 TBA 值, 最

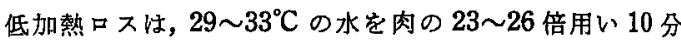
以内晒すことで得られた。最大弾力は $28 \sim 31^{\circ} \mathrm{C}$ の水を 肉の 25〜30 倍用いることで得られた。これらの結果か ら水温 $31.4^{\circ} \mathrm{C}$, 水量 24 倍で 7.5 分間処理が最適水晒し 条件として得られた。

（中添純一）

\section{魚介類の歩止まり，一般成分，ミネラル含量}

Anthony, J. E., et al.: J. Food Sci., 48, 313 314 (1983).

チェサピーク湾の 6 魚種と 4 種の貝類・甲散類の可食 步留り，一般成分およびミネラル定分析した。かなりの ばらつきがあったが，多くは，高タンバタ (20\%以上)， 低脂肪 (5\%以下) であり，カルミウム，リン，マグネ シウム，カリウムというマクロミネラルのよい給源であ る。ナトリウムとカリウムの比は 1.4 から 1.15 の蠕囲 であった。特にシエルフィッシュは銅，鉄，亜鉛および マンガン等の微量元素の優れた給源である。あの種の貝 類・申殻類は特にミネラル含量が高かった。

(中添純一)

魚類筋肉におけるリジノアラニン形成に及ぼす 熱とアルカリの影翌

MILleR, R., et al.: J. Food Sci., 48, 296 297 (1983).

ルテフィスクやトリポリリン酸ナトリウム処理したフ イレーのようにアルカリ処理した魚肉製品のリジノフラ ニン (LAL) を分析した。いずれの処理をしたもので む, $\mathrm{pH} 8.0$ から 8.5 で通常の加熱温度 $\left(162^{\circ} \mathrm{C}\right)$ で 30 分まで加熱したが LAL は検出できなかった。 $\mathrm{pH} 10$ で $90^{\circ} \mathrm{C} 60$ 分間加熱した試料ではやはり，検出できなかっ たが，pH 12 と 13 て同様に加熱した陚料からは LAL が検出された。徒って，道常の魚の調理方法では LAL 形成に関して問題がない。

（中添純一） 


\section{キチンとキトサンの色素結合特性}

KNORR, D.: J. Food Sci., 48, 36〜37 (1983).

キチン $(\beta(1 \rightarrow 4)-\mathrm{N}$-acetyl-D-glucosamine) およびキ トサン (deacetylated chitin) は，エビ，カ二産業の廃 萧物や副産物として大量に利用が可能である。これらの 食品添加物の担体としての可能性を調べた。FD＆C 赤 の 40 を用いた場合，キチン又はキトサン $1 \mathrm{~g}$ 当り，色 素 0.2 1.6 mg の範囲で，色素濃度とキチン又はキト サンの色素結合能には有意な相関関係があった。キチン の色素結合能は $\mathrm{pH} 2.0 \sim 7.0$ の間で安定であった。キ トサンは $\mathrm{pH} 5.5$ 以下ではゲル化し 評価できなかった が，pH 7.0 から 5.5 の間では安定した色素結合能を 示した。pH 7.0 以上では, キチンもキトサンも色素結 合能が減少するが， pH 2.0 から 6.0 の間では，キチン (0.77 $\mathrm{mg}$ 色素 $/ \mathrm{g}$ キチン) から色素の遊離が見られなか った。 (中添純一)

加熱によって促進されるサメおよびサバ肉の酸敗の抑制

Younathan, M. T., et al.: J. Food Sci., 48, 176 178 (1983).

加熱促進される脂肪の酸敗を天然の抗酸化物質により 抑制する方法として，タマネギ皮部の熱水抽出物（1２ \%)およびタマネギジュース（1％）を用いる方法につ いて検討した。加熱したサメおよびサパ肉の TBA 值は 貯蔵期間および実験条件の遠いにより有意の差が認めら れ，本実験条件の中では，2\%濃度のタマネギ皮部熱水 抽出物の添加がサメおよびサバ肉のいずれに对しても， その酸敗抑制に最も嵱果がみられた。脂肪酸分析の結果

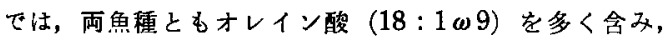
バミチン酸 $(16: 0)$ はサバがサメよりも高い割合で含 まれていた。またドュサへキサェン酸 $(22: 6 \omega 3)$ はサ メよりもサパに高含量諗められた。

(藤井建夫)

\section{シアン化合物生成菌の簡易検出法}

Castric, K. F. and Castric, P. A.: Appl. Environ. Microbiol., 45, 701 702 (1983).

平板 1 枚当り 50 菌株程度によるシフン化水菜生成が 愉出可能な寒天平板法について記載した。微生物によっ て生成されたシアン化合物は，その微生物のコロニ一上 に置かれたペーパーデスク中のアセト酷酸エチル第二銅 や 4,4'-メチレンビス（N,N-ジメチルフニリン）と反応 する。微生物は寒天平板上で多少抑制されつつ堌殖し， コロニーの分離がなされ，シフン化水素の検出能が高め られる。

（森 睠美）

\section{2, 3-ジアミノナフタレンを用いる生物試料中の ナノグラム量のセレンの螢光法による定量}

Hasunuma, R., et al.: Anal. Biochem., 126(2), $242 \sim 245$ (1982).

生物試料中のナノグラム量のセレンか゚，硝酸と過塩素 酸による温式分解後，2３-ジフミノナフタレンを用いる 螢光法によって定量された。螢光とセレン濃度間の線形 関係はセレン $100 \mathrm{ng}$ 以内で認められた。実験誤差はセ レン 5〜25ng の範囲で 4\%以下であった。マグロ筋肉 の抽出物にあらかしめ添加した $2.5 \mathrm{ng}$ のセレンの回収

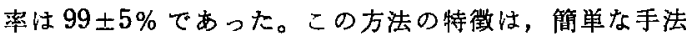
であることと，少量の試料に適していることである。

（安井明美）

修飾された触媒効果の応用：動的な螢光光度法を

用いるミルク試料中のナノグラム量の亜鉛の定量

Moreno, A., et al.: Analyst, 108(1282), 85 91 (1983)

痕跡量の亜鉛（II）定量のための間接的動的螢光光度 法が追べられている。これは，2-とドロキシベンズフル デヒドチオせミカルバゾソの過酸化水素による酸化が マンガン（II）によって触媒される活性化勃果に基づい ている。この反応は酸化生成物の螢光 $(\lambda$ exc. $=365 \mathrm{~nm}$, $\lambda \mathrm{em} .=440 \mathrm{~nm})$ の増师速度で測定することができる。 検量線は亜鉛の $50 \sim 400 \mathrm{ng} / \mathrm{m} l)$ の範囲で直線であり， 正確さは $\pm 2.0 \%$ ある。この方法はほとんど干涉を受 けず，数種の市販のミルク試料中の亜鉛定量に十分適用 された。

(安井明美)

\section{岥酸飲料中の Stevioside および Rebaudioside A} の安定性の研究

Chang, S. S. and Cook, J. M.: J. Agric. Food Chem., 31(2), 409 412 (1983).

リン酸とクエン酸で酸性にした炭酸飲料中の純粋な stevioside そ rebaudioside A の長期間の貯蔵中の安定 性が, 化学的, 微生物学的かつ官能的試験で調べられた。 薄層クロマトグラフィーと高速液体クロマトグラフィー が，これらのステビア甘味料の化学的分解を調べるため に用いられた。いずれの甘味料も，いくらかの分解が $37^{\circ} \mathrm{C}$ で 2 か月貯蔵したあとに観察された。しかし， stevioside では引きつづきき室温で 5 か月，rebaudioside A では 3 か月貯蔵した場合に，有意の变化は認め られなかった。日光に一週間さらした場合， stevioside では影響がなかったが， rebaudioside A では約 $20 \% の$ 損失があった。6 日間 $60^{\circ} \mathrm{C} て ゙$ 加熱すると，0〜6\%の甘 味料の損失があった。 (安井明美) 